INTERNATIONAL JOURNAL OF RESEARCHES IN BIOSCIENCES, AGRICULTURE AND TECHNOLOGY (c) VISHWASHANTI MULTIPURPOSE SOCIETY (Global Peace Multipurpose So cie ty) R. No. MH-659/13(N) www.vmsindia.org

\title{
DIVERSITY OF ROTIFERS IN SONALA DAM, SONALA DIST. WASHIM (M.S.) INDIA
}

\author{
U. P. Mankar ${ }^{1}$ A. D. Bobdev ${ }^{2}$ and V. B. Bhagat ${ }^{3}$ \\ ${ }^{1}$ Research Student, De partment of Zoology, Sevadal Mahila Mahavidyalaya, Nagpur \\ ${ }^{2} \mathrm{Head}$, De partment of Zoology, Shri Shivaji Science College, Nagpur \\ ${ }^{3}$ De partment of Zoology, Shri Shivaji Science College, Akot, Dist. Akola. (M. S.) \\ landeujwala@gmail.com
}

\begin{abstract}
:
Sonala dam is an earthen dam, constructed by irrigation department of Maharashtra Govt. The dam is presently used for irrigation and drinking for regional rural areas. Rotifers are microscopic soft-bodied fresh water invertebrates, which have been used to indicate the tropic status of a water body. They are one of the connecting link organisms between primary producers and consumers in aquatic food we b. The present study reports the occurrence and dive rsity of rotifers in Sonala dam. Sonala, Dist. Washim. Ouantitative assessment of rotifers was undertaken during February 2012 to January 2013. During the study period total 16 species of rotifers were collected from Sonala dam. They were abundant during the winter season and minimum was found in the monsoon season. Conservation of this water body is essential, as this habitat may reveal inte resting rotife $r$ fauna present there.

Keywords: Sonala dam, Diversity, Rotifers, Zooplanktons
\end{abstract}

\section{Introduction}

Studies on fresh water bodies, natural or manmade have recently gained much importance, mainly because of the ir multiple uses. Zooplanktons occupy a central position between the autotrophs and other he te rotrophs. Plankton forms an important component of fish food in aquatic environment and on an important link in food of a fresh water ecosystem. Among the zooplankton, rotifers are appare ntly the most sensitive indicators of water properties. Rotifers are small pseudocoelomate animals that inhabit a wide variety of aquatic habitats (Pejler 1995; Wallace et al., 2006). The habitats of rotifers include both, lentic and lotic environments (Sharma, 2009). They have been widely used in assessment of aquatic pollution due to their sensitivity to small changes in environment, short generation time, parthenogenic mode of reproduction. Rotifers play an integral role in the aquatic food chains due to their qualitative and quantitative occurrence (Vanjare 2013). The occurrence of rotifers is affected by the complex interaction of various physical, chemical, geographical, biological and ecological parameters. The rotifer fauna of freshwater bodies has a potential value as bio-indicators of changing the tropic condition. Some rotifers are highly specialized but most are opportunistic feeders since they consume and assimilate different type s of food.

\section{Materials and Methods}

The present study is a part of limnological survey undertaken (during February, 2012 January, 2013) in Sonala dam, Sonala, Dist. Washim. Sonala Dam rese rvoir was constructed in the year 1981. Agricultural fields surround the reservoir. The rese rvoir is mainly used for drinking water supply to nearby villages and for irrigation. The nearby villages also use the water for bathing and washing purposes. The dam is constructed by irrigation department of Maharashtra Govt. The Sonala dam is located at $77^{\circ}, 12$ ', 30" Longitude and latitude of 20 , 19', 00" in Sonala village of Washim district in Maharashtra (India). It is an earthen dam with 19.20 meter maximum height and 446.90 hector submergence with 132.50 square $\mathrm{Km}$. of catchment area. The dam is presently used for irrigation and drinking for regional rural areas. The reservoir is constructed on the River Aran also known as River Adan a tributary of River Godavari. Adan River in its way runs through the Maraldoh village, before draining in the dam.

The selection of six sampling stations was made on the basis of human and other domestic activities. For biological analysis in water, 50 liter of water sample was filtered through standard plankton net of bolting silk cloth No.25 (56 mesh size). $125 \mathrm{ml}$ was the final volume of the filtered sample which was transferred to another $125 \mathrm{ml}$ plastic bottle and labeled mentioning the time, date and place of sampling. The samples were preserved by adding $2 \mathrm{ml}$ of $4 \%$ formalin. After 24 hours, the supernatant was carefully discarded and the final volume of concentrated sample was $50 \mathrm{ml}$. Preserved $50 \mathrm{ml}$ water sample bottles were brought to the laboratory and examined under a Binocular microscope with different magnification. Quantitative analysis was done by Drop Count Method. Detailed taxonomic 
identification was carried out with Pennak (1989), Koradkar (1992) and Dhanpati (2000).

\section{Observations and Results}

In the present investigation total 16 species of rotifers were recorded in dam water namely Brachionous angularis, Brachionous calyciflorous, Brachionous species, Lecane reculata, Lecane ovalis, Anuraeopsis fissa, Ascomorpha species, Asplancha brrightwalli, Cephadella gibba, Ellosa species, Horaella brehmi, Keratella species, Lepadella ovalis, Lepadella patella, Monostyla species and Trichotria similisstrumosa. Rotifers showed seasonal variations and showed dominance during the winter season. During the study period Anuraeopsis fissa $30.1 \pm 2.5$ ind/1 showed dominance at all stations followed by Cephadella gibba $27.5 \pm 1.2$ ind/1, Lepadella patella $21.5 \pm 1.0 \mathrm{ind} / 1$ and Monostyla species $19.7 \pm 1.0 \mathrm{ind} / 1$. Least appearance was shown by Ellosa species $4.4 \pm 3.5$ ind/1. Stationwise abundance of rotifers was in the order Station $\mathrm{S}_{6}>$ Station $\mathrm{S}_{2}>$ Station $\mathrm{S}_{3}>$ Station $\mathrm{S}_{1}>$ Station $\mathrm{S}_{5}>$ Station $\mathrm{S}_{4}$. Pollution indicator species from Rotifers such as Cephalodella gibba, Lepadella patella and Monostyla species were abundant at stations $\mathrm{S}_{1}, \mathrm{~S}_{2}, \mathrm{~S}_{3}$ and $\mathrm{S}_{6}$.

Table No. 1. Station wise Ave rage values of Zooplank to ns during year 2012-2013

\begin{tabular}{|c|c|c|c|c|c|c|c|c|c|c|c|c|c|c|}
\hline Sr.No & Plankton & & $s_{1}$ & & $\mathbf{S}_{2}$ & & $\mathbf{S}_{3}$ & & $\mathbf{S}_{4}$ & & $\mathbf{S}_{\mathbf{5}}$ & & $\mathbf{S}_{6}$ & Average \\
\hline \multicolumn{15}{|c|}{ Rotifera } \\
\hline 1 & $\begin{array}{l}\text { Anuraeopsis } \\
\text { fissa }\end{array}$ & 30.8 & \pm 2.5 & 35.8 & \pm 2.3 & $31.7=$ & \pm 2.0 & 22.5 & \pm 1.5 & 21.7 & \pm 1.9 & 38.3 & \pm 2.8 & $30.1 \pm 2.5$ \\
\hline 2 & $\begin{array}{l}\text { Ascomorpha } \\
\text { species }\end{array}$ & 29.2 & \pm 1.8 & 33.3 & \pm 2.0 & $30.0=$ & \pm 2.4 & 23.3 & \pm 1.7 & 21.7 & \pm 1.8 & 35.8 & \pm 2.5 & $28.9 \pm 1.4$ \\
\hline 3 & $\begin{array}{l}\text { Asplancha } \\
\text { brrightwalli }\end{array}$ & 6.7 & \pm 4.5 & 9.2 & \pm 5.9 & $7.5=$ & \pm 5.1 & 9.2 & \pm 5.9 & 10.0 & \pm 6.5 & 8.3 & \pm 5.5 & $8.5 \pm 5.6$ \\
\hline 4 & $\begin{array}{l}\text { Brachionus } \\
\text { angulariis }\end{array}$ & 5.8 & \pm 4.1 & 8.3 & \pm 5.2 & & \pm 4.1 & 9.2 & \pm 5.9 & 8.3 & \pm 5.5 & 8.3 & \pm 5.7 & $7.6 \pm 5.1$ \\
\hline 5 & $\begin{array}{l}\text { Brachionus } \\
\text { calyciflorous }\end{array}$ & 6.7 & \pm 4.7 & 9.2 & \pm 5.9 & 6.7 & \pm 4.7 & 10.8 & \pm 7.1 & 11.7 & \pm 7.6 & 9.2 & \pm 6.2 & $9.0 \pm 6.0$ \\
\hline 6 & $\begin{array}{l}\text { Brachionus } \\
\text { species }\end{array}$ & 3.3 & \pm 2.9 & 7.5 & \pm 5.2 & $5.8=$ & \pm 4.3 & 5.8 & \pm 4.3 & 8.3 & \pm 6.0 & 5.0 & \pm 3.5 & $6.0 \pm 4.4$ \\
\hline 7 & $\begin{array}{l}\text { Cephallodell } \\
\text { gibba* }\end{array}$ & 29.2 & \pm 2.1 & 31.7 & \pm 2.2 & $30.0=$ & \pm 2.6 & 19.2 & \pm 1.2 & 18.3 & \pm 1.8 & 36.7 & \pm 23 & $27.5 \pm 1.2$ \\
\hline 8 & $\begin{array}{l}\text { Ellosa } \\
\text { Species }\end{array}$ & 3.3 & \pm 2.9 & 3.3 & \pm 2.8 & 3.3 & \pm 3.3 & 5.8 & \pm 4.2 & 5.8 & \pm 4.2 & 5.0 & \pm 3.6 & $4.4 \pm 3.5$ \\
\hline 9 & $\begin{array}{l}\text { Horaella } \\
\text { brehmi }\end{array}$ & 5.0 & \pm 4.0 & 3.3 & \pm 2.8 & 4.2 & \pm 3.7 & 3.3 & \pm 2.9 & 7.5 & \pm 5.2 & 6.7 & \pm 5.3 & $5.0 \pm 4.0$ \\
\hline 10 & $\begin{array}{l}\text { Keratella } \\
\text { species }\end{array}$ & 14.2 & \pm 1.1 & 19.2 & \pm 1.5 & $15.8=$ & \pm 1.0 & 12.5 & \pm 1.9 & 12.5 & \pm 1.0 & 22.5 & \pm 1.9 & $16.1 \pm 1.2$ \\
\hline 11 & $\begin{array}{l}\text { Lecane } \\
\text { raculta }\end{array}$ & 4.2 & \pm 3.3 & 4.2 & \pm 3.2 & 4.2 & \pm 3.7 & 5.0 & \pm 4.0 & 5.0 & \pm 4.0 & 5.0 & \pm 3.7 & $4.6 \pm 3.7$ \\
\hline 12 & $\begin{array}{l}\text { Lecane } \\
\text { species }\end{array}$ & 7.5 & \pm 5.5 & 10.0 & \pm 7.5 & 9.2 & \pm 7.0 & 7.5 & \pm 5.1 & 10.0 & \pm 6.9 & 13.3 & \pm 1.8 & $9.6 \pm 7.0$ \\
\hline 13 & $\begin{array}{l}\text { Lepadella } \\
\text { ovalis }\end{array}$ & 4.2 & \pm 3.2 & 5.0 & \pm 4.0 & 4.2 & \pm 3.2 & 7.5 & \pm 5.2 & 5.8 & \pm 4.4 & 6.7 & \pm 4.7 & $5.6 \pm 4.1$ \\
\hline 14 & $\begin{array}{l}\text { Lepadella } \\
\text { patella* }\end{array}$ & 20.0 & \pm 1.3 & 25.8 & \pm 1.7 & $20.0=$ & \pm 1.4 & 19.2 & \pm 1.4 & 20.0 & \pm 1.9 & 24.2 & \pm 1.5 & $21.5 \pm 10$ \\
\hline 15 & $\begin{array}{l}\text { Monostyla } \\
\text { species* }\end{array}$ & 20.8 & \pm 1.3 & 22.5 & \pm 1.5 & $20.0=$ & \pm 1.7 & 15.0 & \pm 1.6 & 15.0 & \pm 1.6 & 25.0 & \pm 1.4 & $19.7 \pm 1.0$ \\
\hline 16 & $\begin{array}{l}\text { Trichotria } \\
\text { similisstrumosa }\end{array}$ & 7.5 & \pm 5.1 & 9.2 & \pm 6.1 & 7.5 & \pm 5.1 & 5.8 & \pm 4.4 & 5.8 & \pm 4.4 & 10.0 & \pm 6.7 & $7.6 \pm 5.3$ \\
\hline
\end{tabular}

\section{Discussion}

Data harvested during the study period, Rotifers showed dominance during the winter season and minimum was found in the monsoon season. Maximum diversity of rotifers found in winter season which may be due to the abundance in the food. Less diversity during monsoon may be due to rainfall and heavy floods and less food available. (Sharma et al., 2013). Present observations of Rotifers in Sonala Dam were similar with the observations of Edmondson
(1965), Dhanpati (2000), Kumar (2001), Sitre S. R.(2012) and Sharma (2013). Edmondson (1965) observed high rotifer population in winter, which could be attributed to the favorable temperature and the availability of abundant food in the form bacteria, nanoplanktons and suspended particles. Present study, reports rich rotifer population represented by 16 species. Rotifers were found in maximum at stations, $\mathrm{S}_{1}, \mathrm{~S}_{3}$, and $\mathrm{S}_{6}$ during winter. In the present investigation, low nutrient level has been recorded but the 
influence of water temperature was found negative. Rotifers are chiefly freshwater forms and presence of these organisms in abundance is related to suitable conditions for their survival (Dhanpati, 2000). The diversified rotifer fauna of lake can be linked to favorable conditions and availability of abundant food in the form of bacteria, nanoplankton and suspended detritus in the lake water (Sitre S. R. 2012).During monsoon season lower values of rotife $r$ population density and diversity was observed which could be due to dilution of water resulting in less nutrients (Kumar, 2001).

Three pollution indicators species were observed during the study period among the observed rotifers, Cephallodella gibba, Lepadella patella and Monostyla species and they were abundantly found at stations $\mathrm{S}_{1}, \mathrm{~S}_{2}$, $\mathrm{S}_{3}$ and $\mathrm{S}_{6}$. The specific distribution of pollution indicators indicated different food habits and presence of pollutant in water at station $\mathrm{S}_{1}, \mathrm{~S}_{3}$ and $\mathrm{S}_{6}$ where the water depth was shallow in which the activities of domestic animals and human being with respect to washing and bathing were predominant. These factors were responsible for creation of unstable conditions and the re fore, much pollutant tole rant species we re observed from sampling stations $\mathrm{S}_{1}, \mathrm{~S}_{3}$ and $\mathrm{S}_{6}$. Sudzaki (1964) also observed more resistant species of rotifers at unstable polluted zone of various lakes in Japan. Rotifers are considered as ideal indicators of water quality assessment (Berzens 1989). More work is still required to study regional indicator species from diffe re nt parts of India. It is presumed that rotifers utilize the nutrients as well as phytoplankton more rapidly to build up their population. This may be the reason for the worldwide distribution of Rotifers (Peenak 1978).

\section{Conclusion}

Sonala dam is nutrient rich and contain diversified rotifer fauna. Rotifers are microscopic soft-bodied fresh water invertebrates, which have often been used to indicate the tropic status of a water body. Rotifers utilize the nutrients as well as phytoplankton more rapidly to build up their population and due to their enormous reproductive potential; they play a significant role in aquatic ecosystem to maintain the ecological balance. They were most abundant during winter season and showed least abundance during monsoon season.

\section{References}

APHA, (1998): Standard methods for the examination of water and wastewater 20 theds. American Public Health Association. American water works Association WaterEnvironment Federation. Washington, D.C.

Berzens, B. and Pejler, B. (1989): Hydrobiologia, 27: 171-180.

Edmondson, W. T. (1965): Reproductive rate of plank tonic rotifers as related to food and te mperature. Ecol Manoir., 35: 61-111.

Dhan pathi, M.v.s.S.S (2000): Taxonomic notes on the rotifers from India, IAAB, Hyderabad, 178.

Kodarkar, M. S. (1992): Methodology for water analysis, physico-chemical biological and microbiological. Indian Association of Aquatic Biologists, Hydeabad, Publ. 2: pp.50.

Kumar, K. S. (2001): Studies on freshwater copepods and cladocera of Dharmapuri Dist. Tamil Nadu. J.Aqua.Biol. 16 (1 \& 2): 5-10.

Pejler, B. (1995): Relation to habitat in rotifers. Hydrobiologia 313-314: 267-278.

Pennak, R. W. (1978): Freshwater invertebrates of the United States, $2^{\text {nd }}$ Ed. New York: John Wiley-Interscience Pp.803.

Pennak, R. W. (1989): Fresh water inverte brates of the United States 2/e. 628: John Wiley and Sons Inc., New York.

Sharma, B. K. (1983): The Indian Species of the genus Brachionus (Eurotatoria, Monogonata, Brachionidae), Hydrobiologia, Vol.104: 31-39.

Sharma, B. K. (2009): Diversity of Rotifers (Rotifera: Eurotatoria) of Loktak lake, northeastern India. Tropical Ecology 50 (2): 277-2 85.

Sharma, S., Solanki C. M., Sharma D., Zahoor Pir (2013): Distribution and diversity of zooplanktons in Madhya Pradesh, India. Inte mational Joumal of Advanced Research, 1(1): 16-21.

Sitre, S. R. (2012): Assessment Of Biodiversity Of Rotifers In Ambazari Lake Of Nagpur City With Respect To Water Quality International Interdisciplinary Research Journal, \{Bi-Monthly\}, Volume-II, Issue-II 104-110.

Sudzaki, M. (1964): New systematical approach to the Japanese planktonic rotararia. Hydrobiologia, 23(1): 1-25.

Vanjare - Pai (2013): Ecology of freshwater rotifera in a seasonal pond of the University of Pune (Maharashtra, India) Applied Ecology and Environmental Research 11(4): 525-539.

Wallace, R. L., Snell, T. W., Ricci, C., and Nogrady, T. (2006): Rotife ra: Biology, Ecology and Systematics. In: Guides to the identification of the microinvertebrates of the continental waters of the world (Eds. Segers, H., and D). 